\title{
Factors Affecting Telemedicine Acceptance in Patients With Parkinson's DISEASE
}

\section{Nasim Saboorizadeh ${ }^{*}$ (i) , Mohammad Firoozabadi1 ${ }^{(\mathbb{D})}$, Niloofar Mohammadzadeh²}

${ }^{1}$ Department of Medical Informatics, Faculty of Medical Sciences, Tarbiat Modares University, Tehran, Iran.

${ }^{2}$ Department of Health Information Management, Faculty of Allied Medical Sciences, Tehran University of Medical Sciences, Tehran, Iran.

\begin{tabular}{ll}
\hline Article Info & A B S T R A C T \\
\hline $\begin{array}{l}\text { Article type: } \\
\text { Research }\end{array}$ & Introduction: \\
\hline $\begin{array}{l}\text { Article History: } \\
\text { Received: } 2018-10-07\end{array}$ & Many diseases require constant monitoring todays, and online \\
Revised: $2018-10-23$ & communication with patients for timely intervention is necessary. In this \\
Accepted: $2019-10-22$ & study, based on the results of these studies, we investigated the factors \\
& affecting telemedicine admission in Parkinson's patients.
\end{tabular}

Accepted: 2019-10-22

\section{* Corresponding author: \\ Nasim Saboorizadeh \\ Department of Medical Informatics, \\ Faculty of Medical Sciences, Tarbiat \\ Modares University, Tehran, Iran. \\ Email: \\ nasimsaboorizadeh@modares.ac.ir}

\section{Material and Methods:}

This research was a descriptive survey. The tool of this research is a researcher-made questionnaire that was based on library and internet studies in valid databases such as Medline, Science direct (Elsevier), and searching for original research articles between 2000 and 2017. To search for keywords in the design of a telemedicine software, Parkinson's disease, Technology Acceptance Model in English-language databases.

The questions were designed with the Likert spectrum. The validity of the questionnaire was assessed by the opinions of five experts. Content validity index was measured and item with CVI score higher than 0.79 was considered appropriate. Reliability was assessed through Cronbach's alpha. Statistical sample was determined using sample size determination method in two cities of Tehran and Shiraz. In this study, structural equation modeling (SEM) was used. SPSS software version 16 was used for data analysis. The final data analysis was done by modeling in Smart PLS version 3 software

Results:

For each t-statistic, the path between the two variables was examined, and the statistics whose magnitude was greater than 1.96, at a confidence level of $95 \%$, considering the same path that represents the strength and power of the effect between the two variables, the research hypotheses were statistically and in sample. Examined. Of the 19 hypotheses considered for the adoption of the research technology model, 16 were accepted.

\section{Conclusion:}

Ease of use is one of the most influential factors on attitudes in Parkinson's patients in Iran. Technology anxiety is one of the most important factor that reduce the acceptance of portable smart systems. The Parkinson's patient user does not recognize recreation as a useful system, but the inclusion of educational content to promote health in the program will make Parkinson's patients more welcomed. If the software is prescribed by the therapist, its acceptance rate in Parkinson's patients will increase.

Keywords:

Parkinson's Disease, Technology Acceptance Model, Telemedicine Software.

How to cite this paper

Saboorizadeh N, Firoozabadi M, Mohammadzadeh N. Factors Affecting Telemedicine Acceptance in Patients with Parkinson's Disease. Front Health Inform. 2019; 8(1): e23. D0I: 10.30699/fhi.v8i1.158 
Parkinson's is a chronic disease and a type of neuromuscular disorder that occurs due to the analysis of dopamine-producing brain cells (a type of neurotransmitter) often in old age and over 60 years. Due to its high social impact and high incidence of the disease, it has been chosen as the second neurological disorder after Alzheimer's disease [1]. Approximately $66 \%$ of patients develop disability within the first 5 years and $80 \%$ after 10 years. There are currently about 4 million people with the disease, which is projected to double by 2030 by the current number [2]]. The current treatments for the disease are symptomatic and not permanent. But research is continuing to discover other therapies [ $[\underline{3}, \underline{4}]$. Patients with Parkinson's disease due to lack of definitive treatment, reduced ability to perform daily tasks, symptoms of dementia and many other problems such as impaired vision, anxiety, depression, insomnia, insomnia, fatigue and pain, other cognitive and sensory problems that All are progressively developing in the individual patient, needing more attention $[\underline{5}, \underline{6}]$. One of the new approaches today that can be easily applied due to advances in technology and IT infrastructure is telemedicine. This technology can cover people with chronic illnesses who need further treatment []]. Electronic health can help improve the quality of health care, reduce costs, and facilitate health research [요의. Many studies of telemedicine for Parkinson's patients $[\underline{2}, \underline{10}-\underline{15}]$ have demonstrated the efficacy of using this technology and have also expanded new resources and support groups. Some of the symptoms of Parkinson's include tremors, muscle stiffness, movement disorders, dementia, and imbalances. Motor disorders and dementia can be well managed by telemedicine because they are visually assessed, limited in movement, and require continuous multilateral care. Telemedicine capabilities can be useful in personal care (including chronic diseases such as diabetes, heart failure, and the like) that require constant and momentary control of patients or others throughout their lives. Telemedicine in this area can be of particular benefit to Parkinson's patients, health care providers, and the community. Improving patient and family comfort, improving health, well-being, empowerment, access to more information, quality of life and increased satisfaction [16], disseminating information to a large number of people, reducing inequality, overcoming physical and geographical barriers, training and upgrading Professional skills, and minimizing costs are some of the benefits of telemedicine in the field of health [17]. Increasing clinical effectiveness and cost reduction, maximizing end-user health benefits and maximizing individual revenue stream (organization or department), increasing initiative on time, budget and project goals are other benefits and benefits of using telemedicine software. It is in the community [16]. On the other hand, proper telemedicine use for
Parkinson's patients requires careful planning, identification of requirements and requirements in this area, according to empirical findings derived from the review of hundreds of telemedicine projects over the past decade by the California Telemedicine and E-health Center. Four main pillars of telemedicine including evaluation of disease characteristics, patient-physician relationship, type of IT infrastructure, and type of health services, even empirical findings should be considered as a valuable resource for the development of telemedicine devices [18]. Since optimal pre-design studies lead to reduced error and complexity [19], this study aimed to investigate the factors affecting telemedicine acceptance by Parkinson's patients.

\section{MATERIALS AND METHODS}

This study was conducted in 2017 to determine the factors affecting the adoption of telemedicine technology by Parkinson's patients based on a technology descriptive survey. The tool of this research is a researcher-made questionnaire based on library and internet studies in valid databases such as Medline, Science direct (Elsevier), Google scholar and searching for original research articles between 2000 and 2017.

The keywords "Telemedicine, Parkinson's disease, Technology Acceptance Model" were searched in databases. Also, one of the conditions for selection of articles was the availability of the full text of the articles, as the full text of the article study, the desired indexes could be extracted. The questionnaire consists of two parts: demographic and technology acceptance questions. The questions are designed with the Likert spectrum. The validity of the questionnaire was assessed by the opinions of five experts (faculty members of Medical Informatics and Health Information Management, Tarbiat Modares University, Tehran and Iran University of Medical Sciences). Content validity index was measured by dividing the total number of points for the relevant item (only three and four) by the total number of responses and the item was identified as having a CVI score above 0.79. Reliability was assessed by Cronbach's alpha coefficient. The population of the study was 150000 to 160,000 people with Parkinson's disease in Iran.

The sample size was 84 . Due to the limited number of patients available compared to the reported statistics, very few refer to clinics for treatment, so questionnaires in both Tehran and Shiraz, at all clinics and hospitals and all patients available during one visit. Year was distributed. Structural equation modeling (SEM) is used in this study. It is a multivariate technique that uses multivariate regression and factor analysis to estimate the dependency relationships between variables. In this study, structural equations with partial least squares 
approach were used to analyze data for technology adoption model due to relatively small sample size and data normalization.

Descriptive statistics were used for data analysis and then inferential statistics were expressed using structural equation approach. The descriptive part of the present study is provided by SPSS Version 8 software, and the data collected in the same SPSS software for modeling were prepared and modified for analysis prior to starting the inferential statistics analysis in Eveiws Version 3 software for modeling. The final data were modeled in Smart PLS version 3 software. The research model is based on the two well-known models of STAM and TAM2, so the relationships assumed between the variables in these models remain the same, and then their validity is evaluated based on Parkinson's patients' views of portable smart systems technology. In addition, by combining the two models and adding new structures, new relationships have been formed whose validity has also been tested.

There were 13 variables in the proposed technology acceptance model including technology anxiety, facilitation conditions, individual health status reporting, physical performance, mental ability, negative mental perception, expert confidence, perceived usefulness, perceived usefulness, and health promotion. Entertainment as perceived usefulness, education as perceived usefulness, perceived ease of use and attitude to use. Perceived usefulness variables, perceived ease of use and intent to use endogenous and dependent variables are listed as independent and exogenous variables. Initial model based on technology acceptance model is shown in Fig 1.

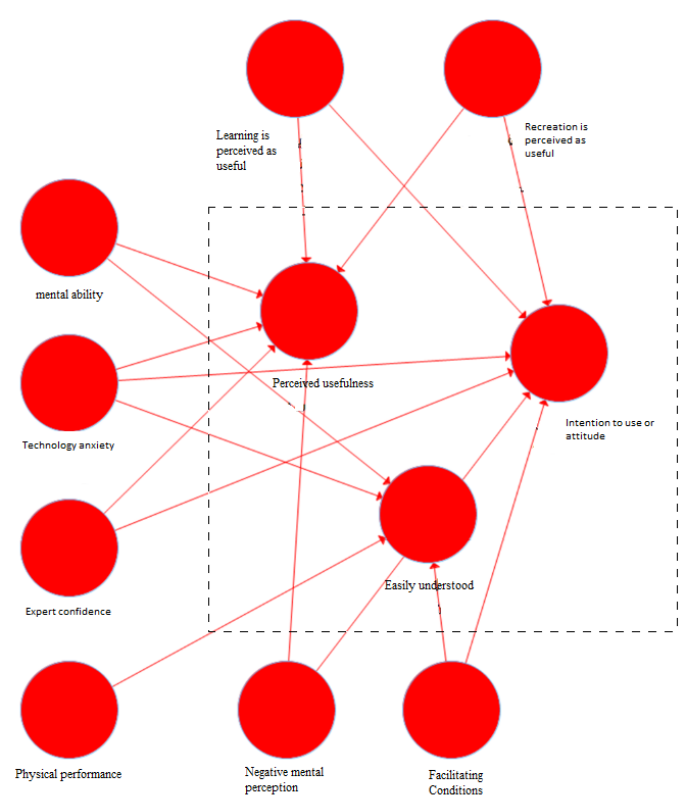

Fig 1: Initial model based on technology acceptance model

\section{RESULTS}

In order to be sure of the results of the research model, there are some indicators that are presented under the heading of model evaluation method, model evaluation at structural level and overall fitting of expression model and are included in the relevant tables. Cronbach's alpha coefficient and Structural reliability coefficient were calculated. In addition, to ensure the reliability of the index, all factor loadings of the indexes must be greater than 0.7 and at least significant at the level of 0.5. AVE is also used to evaluate convergence validity in Smart PLS software [20, 21].

Diagnostic validity indicates the existence of partial correlations between indices of one construct and indices of other constructs evaluated in the model [22] and also the Fornell-Larcker criterion [르, 21] can be used. At the structural level, we also evaluate the model. The first key criterion used in SmartPLS software is the $\mathrm{R}^{2}$ determination coefficient [22]. Redundancy is an index of validity or redundancy, which indicates the quality of the structural model, and Communality is an index of validity of crossvalidation or cross-validation [22].

The next step in evaluating structural models is to evaluate the pathway between the latent variables in the model, which was performed using algebraic sign coefficient, size, and significance level. In the last step, we examine the overall fit of the model. Unlike covariance-based models, the PLS model does not have multiple fit indices, but according to Amato et al. the GOF index in the PLS can act as the general fit indices of the model and to evaluate the validity or quality of the model [1]]. PLS in general. The GOF is calculated using the following formula: [를

$$
\text { GOF }=\sqrt{ }\left(\overline{\text { communality }} \cdot \overline{R^{2}}\right)
$$

Watzels et al. reported three values of $0.19,0.25$ and 0.36 as the GOF values for low, medium and strong, respectively [23]. The GOF value calculated for the present research model; 0.63 indicates a perfectly good fit of the model (Table 1-3). 
Table 1: Internal and external criteria of research hypotheses model

\begin{tabular}{|c|c|c|c|c|c|c|c|}
\hline 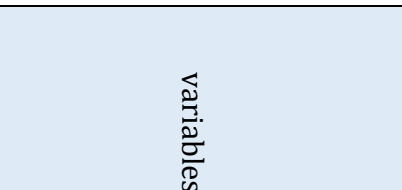 & 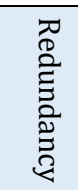 & 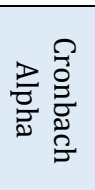 & 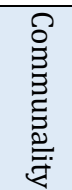 & 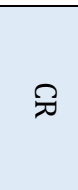 & 总 & 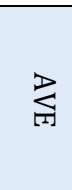 & 尺ิ \\
\hline Technology anxiety & - & .889 & .495 & .760 & - & .514 & \multirow[t]{11}{*}{.63} \\
\hline Expert confidence & - & .945 & .421 & .741 & - & .699 & \\
\hline Negative mental perception & - & .791 & .234 & .710 & - & .657 & \\
\hline $\begin{array}{l}\text { Recreation is perceived as } \\
\text { useful }\end{array}$ & - & .808 & .221 & .887 & - & .725 & \\
\hline One's mental ability & - & .902 & .411 & .801 & - & .577 & \\
\hline Easily understood & .457 & .760 & .509 & .789 & .617 & .891 & \\
\hline Perceived usefulness & .420 & .721 & .524 & .841 & .655 & .640 & \\
\hline Facilitating conditions & - & .985 & .324 & .717 & - & .766 & \\
\hline One's physical performance & - & .721 & .460 & .745 & - & .679 & \\
\hline Intention to use or attitude & .632 & .834 & .386 & .885 & .941 & .612 & \\
\hline $\begin{array}{l}\text { Learning is perceived as } \\
\text { useful }\end{array}$ & - & .725 & .585 & .829 & - & .551 & \\
\hline
\end{tabular}

Table 2: Fornell-Larcker benchmarking model of research theories

\begin{tabular}{|c|c|c|c|c|c|c|c|c|c|c|c|}
\hline & 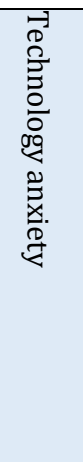 & 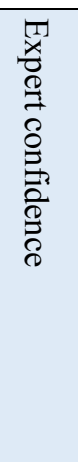 & 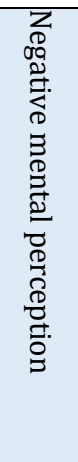 & 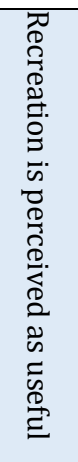 & 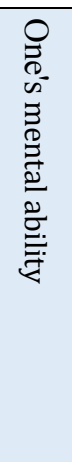 & 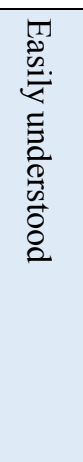 & 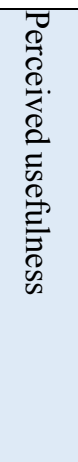 & 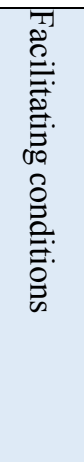 & 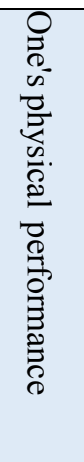 & 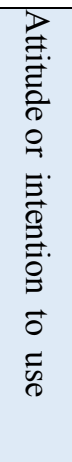 & 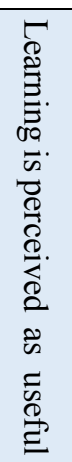 \\
\hline Technology anxiety & .717 & & & & & & & & & & \\
\hline Expert confidence & .677 & .836 & & & & & & & & & \\
\hline Negative mental perception & .698 & .766 & .810 & & & & & & & & \\
\hline $\begin{array}{l}\text { Recreation is perceived as } \\
\text { useful }\end{array}$ & .444 & .731 & .601 & .851 & & & & & & & \\
\hline One's mental ability & .693 & .679 & .621 & .654 & .795 & & & & & & \\
\hline Easily understood & .680 & .778 & .502 & .629 & .691 & .943 & & & & & \\
\hline Perceived usefulness & .486 & .541 & .443 & .686 & .535 & .841 & .800 & & & & \\
\hline Facilitating conditions & .540 & .712 & .456 & .427 & .429 & .557 & .444 & .875 & & & \\
\hline One's physical performance & .548 & .344 & .301 & .237 & .100 & .569 & .102 & .445 & .824 & & \\
\hline Attitude or intention to use & .498 & .700 & .115 & .541 & .223 & .485 & .333 & .542 & .465 & .732 & \\
\hline $\begin{array}{l}\text { Learning is perceived as } \\
\text { useful }\end{array}$ & .210 & .800 & .200 & .243 & .110 & .150 & .460 & .368 & .207 & .237 & .742 \\
\hline
\end{tabular}


Table 3: Summary of research assessment results

\begin{tabular}{|l|l|l|l|}
\hline Hypothesis & T values & $\begin{array}{l}\text { Path } \\
\text { coefficient }\end{array}$ & $\begin{array}{l}\text { The result of } \\
\text { hypotheses }\end{array}$ \\
\hline Perceived usefulness has a positive effect on intention to use. & 4.51 & 0.13 & Approved \\
\hline Perceived ease of use has a positive effect on intention to use. & 2.82 & 0.33 & Approved \\
\hline Perceived ease has a positive effect on perceived usefulness. & 6.86 & 0.36 & Approved \\
\hline $\begin{array}{l}\text { Recreation as perceived usefulness has a positive effect on } \\
\text { perceived usefulness. }\end{array}$ & .88 & 0.20 & Unverified \\
\hline $\begin{array}{l}\text { Recreation as a perceived usefulness has a positive effect on } \\
\text { intention to use. }\end{array}$ & 3.82 & 0.22 & Approved \\
\hline $\begin{array}{l}\text { Learning as perceived usefulness has a positive effect on } \\
\text { perceived usefulness. }\end{array}$ & .22 & 0.41 & Unverified \\
\hline $\begin{array}{l}\text { Learning as perceived usefulness has a positive effect on intention } \\
\text { to use. }\end{array}$ & 5.43 & 0.57 & Approved \\
\hline Technology anxiety has a negative impact on perceived ease. & 2.70 & -.68 & Approved \\
\hline $\begin{array}{l}\text { Technology anxiety has a negative impact on perceived } \\
\text { usefulness. }\end{array}$ & 6.71 & -.14 & Approved \\
\hline Technology anxiety has a negative impact on intention to use. & 4.16 & -.15 & Approved \\
\hline Facilitating conditions have a positive effect on perceived ease. & 3.56 & .11 & Approved \\
\hline Conditions of facilitation have a positive effect on intention to use. & 5.22 & .13 & Approved \\
\hline $\begin{array}{l}\text { Negative mental perception has a negative effect on intention to } \\
\text { use. }\end{array}$ & 5.11 & -.16 & Approved \\
\hline $\begin{array}{l}\text { Negative mental perception has a negative effect on perceived } \\
\text { usefulness. }\end{array}$ & 3.21 & -.24 & Approved \\
\hline Trust in the expert has a positive effect on perceived usefulness. & 2.97 & .57 & Approved \\
\hline Trust in the expert has a positive effect on intention to use. & 2.90 & .45 & Approved \\
\hline One's physical performance has a direct effect on ease of use. & 5.93 & .65 & Approved \\
\hline One's mental ability has a direct impact on ease of use. & 0.17 & .32 & Unverified \\
\hline One's mental ability has a direct impact on perceived usefulness. & 6.21 & .24 & Approved \\
\hline
\end{tabular}

Of the19 hypotheses considered for the adoption of the research technology model, 16 were accepted and the rest were rejected because of not obtaining the minimum required $\mathrm{T}$-statistic at the $90 \%$ confidence level. The value of the path coefficient (which is the beta model of the model) is compared at the significance level of $90 \%, 95 \%$, and $99 \%$, with the minimum $t$ statistic being equal to $1.64,1.96$, and 2.58 , respectively. The following will discuss the acceptance or rejection of the assumptions of the technology adoption model.

\section{DISCUSSION}

Past studies, which are comparatively observable in Table 4, confirmed the positive and direct influence of perceived ease of use on attitude toward use in the area of Davies technology acceptance, and in the current study this relationship was calculated significant. Other factors influencing technology adoption by Parkinson's patients have been used by Chen et al. [24] and the technology adoption model 2 developed by Vankatesh and Davis. Many of the relationships that were confirmed in the technology adoption model in both studies were confirmed in the current study. Factors such as perceived usefulness, perceived ease of use, and facilitating conditions influenced attitudes toward patient use.
Experts' trust and perceived usefulness had a direct and positive effect on intention to use, and technology anxiety had a significant negative effect on intention to use.

In previous studies, no research has been found to directly use the technology acceptance model questionnaire to measure patients' approaches. The purpose of this part of the current study was to better understand patients first and then to perform the validity and reliability of the technology acceptance model questionnaire for Parkinson's patients so that it can be used when implementing the proposed sample software framework. Previous research on the impact of telemedicine on patients and their lives is presented in Table 4.

\section{CONCLUSION}

In chronic Parkinson's disease, which requires almost constant care, medical services must be available to the community and often at home to keep their disease under control and prevent its exacerbation. Telemedicine has a significant impact on the quality of life of these individuals and their control and treatment through online communication with the physician and following the improvement process through direct communication with the physician. 
Table 4: Comparison of researches done to evaluate the impact of telemedicine on patients

\begin{tabular}{|l|l|l|l|l|l|l|}
\hline Result & Design & method & $\begin{array}{l}\text { Sample } \\
\text { Size }\end{array}$ & Country & Year & Author \\
\hline $\begin{array}{l}\text { Increase } \\
\text { the quality } \\
\text { of life }\end{array}$ & $\begin{array}{l}\text { Randomized } \\
\text { controlled } \\
\text { trial }\end{array}$ & $\begin{array}{l}\text { Tele- Nursing via } \\
\text { video }\end{array}$ & 14 & America & 2011 & $\begin{array}{l}\text { Dorsey et al. } \\
{[12]}\end{array}$ \\
\hline $\begin{array}{l}\text { Increasing } \\
\text { medical } \\
\text { knowledge }\end{array}$ & $\begin{array}{l}\text { controlled } \\
\text { trial }\end{array}$ & $\begin{array}{l}\text { Video Conference } \\
\text { Distance Learning }\end{array}$ & 33 & America & 2015 & Cubo et al. [2] \\
\hline $\begin{array}{l}\text { Increasing } \\
\text { innovative } \\
\text { resources }\end{array}$ & Backup group & $\begin{array}{l}\text { Remote support, } \\
\text { questionnaire }\end{array}$ & 8 & America & 2015 & Shah et al. [10] \\
\hline $\begin{array}{l}\text { The effect } \\
\text { of nursing } \\
\text { education } \\
\text { on patient } \\
\text { satisfaction }\end{array}$ & Randomized & Questionnaire & 137 & America & 2015 & Qiang et al. [11] \\
\hline $\begin{array}{l}\text { Proven } \\
\text { implement } \\
\text { ation } \\
\text { capability } \\
\text { and cost } \\
\text { savings }\end{array}$ & $\begin{array}{l}\text { controlled } \\
\text { trial }\end{array}$ & $\begin{array}{l}\text { Technical } \\
\text { infrastructure } \\
\text { review }\end{array}$ & 10 & America & 2011 & $\begin{array}{l}\text { Barroso et al. } \\
{[15]}\end{array}$ \\
\hline $\begin{array}{l}\text { Reduce } \\
\text { provincial } \\
\text { trips and } \\
\text { increase } \\
\text { satisfaction }\end{array}$ & $\begin{array}{l}\text { Randomized } \\
\text { controlled } \\
\text { trial }\end{array}$ & $\begin{array}{l}\text { Questionnaire } \\
\text { Tele-dermatology }\end{array}$ & 91 & Iran & 2013 & $\begin{array}{l}\text { Montazeri et al. } \\
{[13]}\end{array}$ \\
\hline
\end{tabular}

As the findings also show, ease of use is one of the most influential factors on attitude toward use in Parkinson's patients in Iran, and consequently affects physical function. It is also thought to be part of the significant effect of the expert trust construct on the perceived usefulness construct because of the usefulness of an activity as a result of expert prescribing. The patient with Parkinson's disease does not recognize recreation as a useful system, but learning to use it is one of the things he/she is very keen to use if he or she is convinced that he/she is using it instead. It was also shown that there was no significant relationship between mental ability and perceived ease.

Technology anxiety is one of the most important factors that reduce the acceptance of portable smart systems by Parkinson's patients; however, the use of this software has been widely welcomed by many patients with Parkinson's disease. If the software is prescribed by the therapist, its acceptance rate in Parkinson's patients will increase. Including educational content to promote health will make Parkinson's patients more welcoming.

Finally, the use of telemedicine software for Parkinson's patients will improve the provision of health services to Parkinson's patients. The system thus provides the conditions to increase the ability to communicate with the physicians provided at the center as well as access to information.

\section{AUTHOR'S CONTRIBUTION}

All the authors approved the final version of the manuscript.

\section{CONFLICTS OF INTEREST}

The authors declare no conflicts of interest regarding the publication of this study.

\section{FINANCIAL DISCLOSURE}

No financial interests related to the material of this manuscript have been declared.

\section{REFERENCES}

1. Chua KK, Wong A, Chan KW, Lau YK, Bian ZX, Lu JH, et al. A randomized controlled trial of Chinese medicine on nonmotor symptoms in parkinson's disease. Parkinsons Dis. 2017; 2017: 1902708. PMID: 28630780 DOI: 10.1155/2017/1902708 [PubMed]

2. Cubo E, Doumbe J, Njiengwe E, Onana P, Garoña R, Alcalde J, et al. A parkinson's disease tele-education program for health care providers in Cameroon. J Neurol Sci. 2015; 357(1-2): 285-7. PMID: 26190525 DOI: 10.1016/j.jns.2015.07.019 [PubMed]

3. Ran C, Wirdefeldt K, Brodin L, Ramezani M, Westerlund M, Xiang F, et al. Genetic variations and mRNA expression of NRF2 in parkinson's disease. Parkinsons Dis. 2017; 2017: 4020198. PMID: 28540099 DOI: 10.1155/2017/4020198 [ㄹued]

4. Glizer D, MacDonald PA. Cognitive training in 
parkinson's disease: A review of studies from 2000 to 2014. Parkinsons Dis. 2016; 2016: 9291713. PMID: 27688923 DOI: $10.1155 / 2016 / 9291713$ [PubMed]

5. Romenets SR, Wolfson C, Galatas C, Pelletier A, Altman R, Wadup L, et al. Validation of the non-motor symptoms questionnaire (NMS-Quest). Parkinsonism Relat Disord. 2012;18(1): 54-8. PMID: 21917501 DOI: 10.1016/j.parkreldis.2011.08.013 [PubMed]

6. Lim SY, Lang AE. The nonmotor symptoms of Parkinson's disease: An overview. Mov Disord. 2010; 25(Suppl 1): S123-30. PMID: 20187234 DOI: 10.1002/mds.22786 [PubMed]

7. Achey M, Aldred JL, Aljehani N, Bloem BR, Biglan KM, Chan $\mathrm{P}$, et al. The past, present, and future of telemedicine for parkinson's disease. Mov Disord. 2014; 29(7): 871-83. PMID: 24838316 DOI: 10.1002/mds.25903 [ubMed]

8. Mohammadzadeh N, Safdari R. Artificial intelligence tools in health information management. Int J Hosp Res. 2012; 1(1): 71-6.

9. Mohammadzadeh N, Safdari R. Patient monitoring in mobile health: opportunities and challenges. Med Arch. 2014; 68(1): 57-60. PMID: 24783916 DOI: 10.5455/medarh.2014.68.57-60 [PubMed]

10. Shah SP, Glenn GL, Hummel EM, Hamilton JM, Martine RR, Duda JE, et al. Caregiver tele-support group for Parkinson's disease: A pilot study. Geriatr Nurs. 2015; 36(3): 207-11. PMID: 25744558 DOI: 10.1016/j.gerinurse.2015.02.002 [PubMed]

11. Qiang JK, Marras C. Telemedicine in parkinson's disease: A patient perspective at a tertiary care centre. Parkinsonism Relat Disord. 2015; 21(5): 5258. PMID: $25791380 \quad$ DOI: 10.1016/j.parkreldis.2015.02.018 [PubMed]

12. Dorsey ER, Deuel LM, Voss TS, Finnigan K, George BP, Eason $\mathrm{S}$, et al. Increasing access to specialty care: A pilot, randomized controlled trial of telemedicine for parkinson's disease. Mov Disord. 2010; 25(11): 1652-9. PMID: 20533449 DOI: 10.1002/mds.23145 [PubMed]

13. Montazeri M, Bahaadinbeigy K, Tofighi S. Design and implementation a web base teledermatology system to reduce provincial travelling in Kerman univeresity of medical sciences. Health Information Management. 2015; 11(6): 681-8.

14. Hosseini SM, Ziadlou D, Nasiri N, Sayerinia A. Study awareness and attitude volume of personnel of treatment and health services providing centers of Kerman university of medical sciences concerning telemedicine. Iran J Med Inform. 2013; 2(3): 1-7.

15. Barroso MC, Esteves GP, Nunes TP, Silva LMG, Faria ACD, Melo PL, et al. A telemedicine instrument for remote evaluation of tremor: Design and initial applications in fatigue and patients with Parkinson's disease. Biomedical Engineering Online. 2011; 10(1): 14.

16. Brownsell S. Measuring the 'success' of telehealth interventions. Journal of Assistive Technologies. 2009; 3(4): 12-20.
17. Maximino LP, Picolini-Pereira MM, Carvalho JL. Telegenetics: Application of a tele-education program in genetic syndromes for Brazilian students. Journal of Applied Oral Science. 2014; 22(6): 477-83.

18. Ritter LA, Robinette TR, Cofano J. Evaluation of a statewide telemedicine program. Californian Journal of Health Promotion. 2010; 8(1): 1-9.

19. Vander Werf M. Ten critical steps for a successful telemedicine program. Stud Health Technol Inform. 2004; 104: 60-8. PMID: 15747964 [PubMed]

20. Fornell C, Larcker DF. Evaluating structural equation models with unobservable variables and measurement error. Journal of Marketing Research. 1981; 18(1): 39-50.

21. Fornell C, Larcker DF. Structural equation models with unobservable variables and measurement error: Algebra and statistics. Journal of marketing research. 1981; 18(3): 382-8.

22. Allahi AF. Step by step tutorial for SmartPLS statistical software. Payame Noor University Press; Tehran: 2014.

23. Davari A. Structural equation modeling with PLS software. Tehran University Press; Tehran: 2014.

24. Chin WW. PLS-graph user's guide. University of Houston; USA. 2001. 